Ethiopian Journal of Environmental Studies \& Management 7(6): 599 - 608, 2014.

ISSN:1998-0507

doi: http://dx.doi.org/10.4314/ejesm.v7i6.2

Submitted: June 05, 2014

Accepted: September 30, 2014

\title{
FLOOD AND CASSAVA PRODUCTIVITY IN KOGI STATE, NIGERIA: A QUANTITATIVE ANALYSIS USING CROSS-SECTIONAL DATA
}

${ }^{*}$ COKER, A. A., ${ }^{1}$ ADEBAYO, C. 0., ${ }^{1}$ ODOEMENA, B.C., ${ }^{2}$ AKOGUN, E.0. ${ }^{3}$ AND EZINNE, C.G. ${ }^{1}$

${ }^{1}$ Department of Agricultural Economics and Extension Technology, School of Agriculture and Agricultural Technology, Federal University of Technology, Minna, P.M.B. 65, Minna, Nigeria.

${ }^{2}$ International Fund for Agricultural Development, IFAD Country Office, FCT, Abuja, Nigeria.

${ }^{3}$ Support to National Programme for Food Security, Project Support Office, Maitama, FCT,

Abuja, Nigeria.

\begin{abstract}
The study assessed the effect of the 2012 flood disaster on cassava productivity in Kogi State and identified the adaptation measures and resilience capacity of the cassava farmers affected by the flood. To achieve the objectives of the study, the "with and without" approach involving the flood affected farmers and control group was employed to ascertain and compare the effect of the flood on cassava productivity. Simple descriptive statistics, productivity index, z-test of two means and multiple regression analysis were employed to analyse the data collected. The result indicated a significant cassava productivity differentials of about $56 \%$ between the flood affected farmers and the control population. The multiple regression analysis result further confirmed that flood had a significant effect on cassava productivity amongst the respondents at $5 \%$ level of significance. Against this backdrop, there is the need for farmers to continue to diversify their farming practices with a view to mitigating the effect of future flood occurrence, adopt drought resistant cassava varieties while the National Emergency Management Agency (NEMA) should in conjunction with the Nigerian Meteorological Agency (NIMET), Kogi State Government and the Media create effective climatic situation awareness for cassava farmers within the State with the view to containing and minimizing the adverse effect of flooding.
\end{abstract}

Key Words: Flood, Disaster, Adaptation, Resilience, Cassava farmers, Productivity

\section{Introduction}

Severe flooding ravaged Nigeria in the months of September and October 2012, disrupting agricultural production and other sectors of Nigeria's economy (National Emergency Management Agency, 2012), in many States of the federation, including Kogi. This was caused by excessive rainfall within Nigeria, as well as water released from Lagdo reservoir in the republic of Cameroun. It washed away farm lands, settlements and other critical infrastructure such as roads, bridges, markets, homes, communication and power installations. Floods are sudden and difficult to predict, they may only last a short while, but their economic effects are devastating if not well managed. Flood has been an inhibiting factor in the development of agriculture, especially in areas subject to frequent flooding. It has also been one of the major factors hindering Africa's population from escaping poverty (Action Aid, 2006). Floods happen for a variety of reasons, but most commonly

*Corresponding Author: Coker, A.A..

Email: ayodejicoker@futminna.edu.ng 
caused by heavy rainfall resulting to a sudden rise in water table and levels of rivers. Flood also occurs when a stream runs out of it confines or banks and submerges surrounding areas (Stephen, 2011). However, the amount of damage caused by a flood depends on its severity and how long it last, but most importantly, on the reliability and availability of measures put in place by the government or local people to receive the flood. Nwaobiala and Nwosu (2014) revealed that agriculture being one of the most weatherdependent human venture suffer due to its vulnerability to climate change. Watson et al. (1997) further observed that African countries are particularly vulnerable to the incidence of climate given their dependence on rain-fed agriculture. FAO (2009) and BNRCC (2012) have all alluded to the positive and negative effects of climate to include extended growing season, enhanced livestock production, constraint to primary and secondary productivity and crop failure. Gichere et al. (2013) noted that in subSaharan Africa, droughts and floods are two extreme climatic events that adversely affect the agricultural sector, and by extension affect the household food consumption. IPCC (2014) reported that for major crops in tropical and temperate regions, climate change without adaptation is projected to negatively impact on production. The report further hinted that climate-change impacts are expected to exacerbate poverty in most developing countries and create new poverty pockets in countries with increasing inequality in both developed and developing countries. It noted that key risk which constitutes an overaching reason for concern (RFC) under climate change assessment has been that of flooding. In Kenya, severe flood arising when major rivers attained record peaks caused havoc and destroyed livelihood (Gadain et al., 2006). However, flooding has its own positive side having been noted to leave alluvial deposits on farm lands while receding. It has also been known to add lots of nutrients to lakes and rivers which benefit fishes and other aquatic lives. Fishes also make use of floods to reach new habitats while avians profit from the boost in production caused by flooding (Bariweni, et al., 2012).

In Kogi State, agriculture is the main source of livelihood of the rural populace with major crops cultivated comprising cassava, yam, maize, rice vegetables amongst others. As a confluence State, the two major rivers (River Niger and River Benue) where heavy down pour drain into in Nigeria converges in the State to drain into the ocean in southern Nigeria. This position of the State makes it highly vulnerable to any pronounced flood in Nigeria. Cassava has been a major staple crop and a key source of income to the rural dwellers in the State. In 2010, the State accounted for $8 \%$ of the total cassava production in the country (NPFS, 2011). The launch of the Agbadu-Alape Cassava Staple Crop Processing Zone (SCPZ) in the State under the on-going Agricultural Transformation Agenda (ATA) further justified the place of cassava in the socioeconomic lives of the farming households in the State. However, the effect of climate on cassava has been a topical one in recent past. Nwaobiala and Nwosu (2014) observed that cassava is drought resistant and can strive under extreme weather condition, having observed that climate proxied by temperature and rainfall had no effect on cassava production. According to Enete (2003), cassava exhibited different growth behaviors and yields in different years as a result of differences in the annual weather conditions, given that extreme climatic conditions has the tendency of affecting soil and water resources. Against the back-drop that a colossal proportion of crop production in Kogi State is rain-fed, the adverse effect of 
climate change outcome such as flood poses a great threat to farmers in the State. Aside these, it is probable that factors such as widespread poverty, human diseases, population density may magnify the negative impacts of climatic events, particularly on the agricultural sector. Thus, justification for this study stems from the need to provide a thorough understanding of the effect of the flood on the productivity of cassava farmers in the study area. The result of the study will be beneficial to the Government of Kogi State for policy formulation, prevention and mitigation of the effect of future adverse climatic effect, especially those of flood. This study therefore addressed the effect of flood on the productivity of cassava farmers in the study area by answering the following research questions: (i) what were the socioeconomic characteristics of cassava farmers in the study area; (ii) what was the effect of flood on cassava productivity; and (iii) what were the strategies adopted by cassava farmers affected by flood in coping with the disaster.

The broad objective of the study was to assess the effect of flood on cassava productivity. The specific objectives were to (i) describe the socio-economic characteristics of the affected farmers in the study area; (ii) ascertain the effect of flood on cassava productivity; and (iii) identify the coping strategies adopted by the affected cassava farmers after the flood disaster.

\section{Methodology \\ Study Area}

The study was undertaken in Kogi State in the North Central of Nigeria. It lies on Latitude $7^{\circ} 30^{\prime} \quad \mathrm{N}$ and Longitude $6^{\circ} 42^{\prime} \mathrm{E}$. The State has a land mass of $1,498 \mathrm{~km}^{2}$ and an estimated population of 3, 115,900 (National Population Commission, 2007). Its vegetation falls within the northern guinea savannah. With 21 Local Government Areas, the State experiences two distinct climatic seasons which are the wet and dry. The wet season is from April/May and terminates in September/October while the dry season is well characterized by very dusty winds emerging from the Sahara desert. The climate and hydrology of the State permits the cultivation of most staple crops (cassava, maize, rice, vegetables) and still allows sufficient opportunities for free grazing, water free fishing and forestry development. Estimated average rainfall is $1,231 \mathrm{~mm}$, mean temperature is $32.7^{\circ} \mathrm{C}$. The main occupations of the indigenes of the state are farming, livestock and fishery production. The latter is of importance given the presence of the Niger and Benue rivers. 


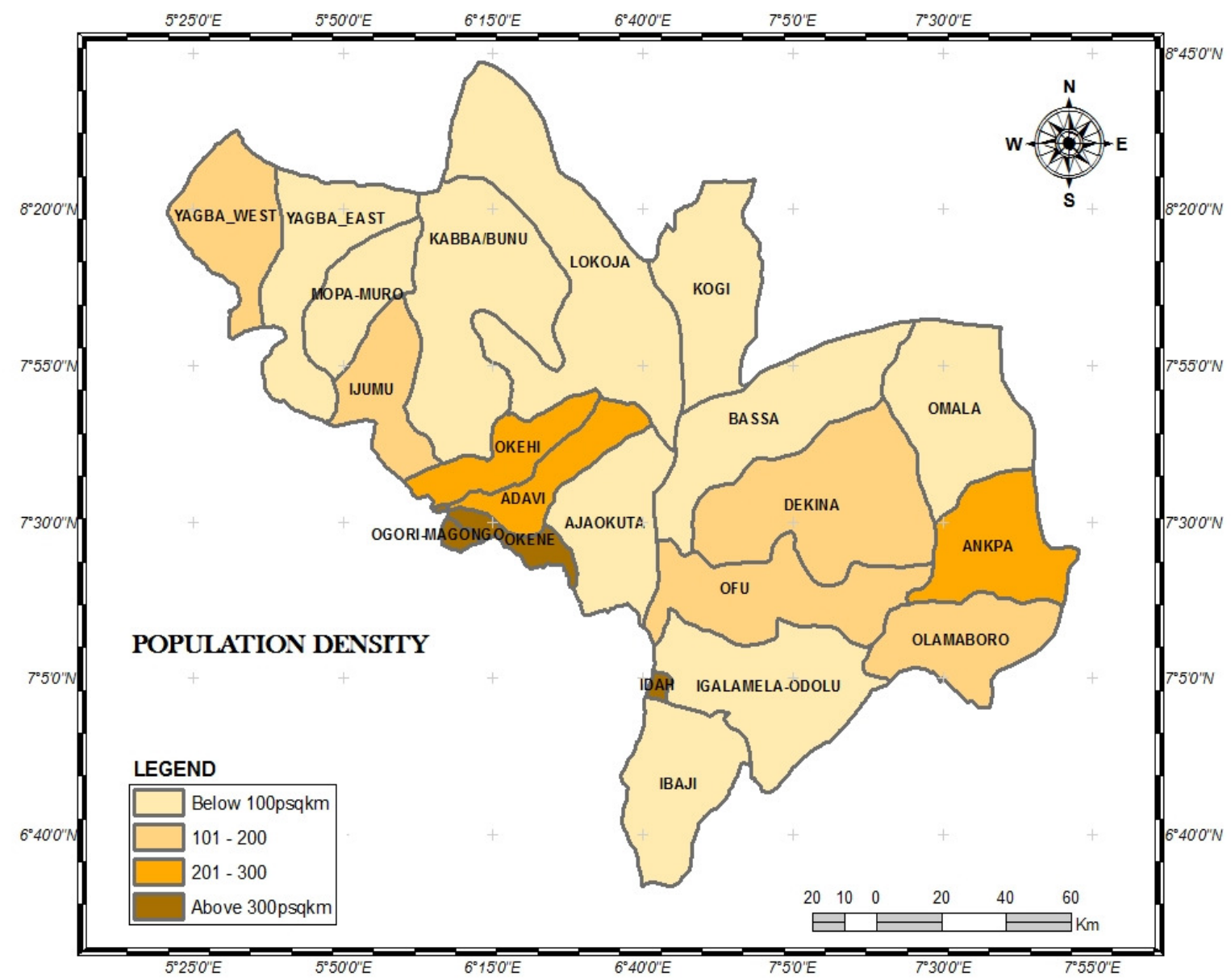

Figure 1: Map of Kogi State Showing the Study Areas

\section{Sampling Design and Data Collection}

To achieve the objective of the study, the "with and without" approach was used involving data collection from both the flood affected and un-affected communities. Multistage sampling procedure was employed for the study. The first stage involved the purposive selection of Kogi State for the study, given the severity of the disaster in the State and the associated influence of both the Niger and Benue rivers. The second stage of sampling covered the selection of 6 Local Government Areas (Bassa, Okene, Kogi, Lokoja, Ibaji and Koton-Karfi) which were severely affected by the flood disaster and 3 Local Government Areas (Dekina, Ankpa and Omala), where considerable numbers of villages were un-affected by the disaster. The lopsidedness in the selection of LGAs was necessary given that substantial numbers of the 21 LGAs in the State were directly or indirectly affected by the flood. In all, 71 respondents were interviewed from 18 communities under the affected LGAs and 49 respondents from 14 un-affected communities from the 3 un-affected LGAs, using the probability proportional to size technique.

\section{Analytical Technique and Model Specifications}

Three models were employed to achieve the objectives of this study. These included 
the (i) Productivity Index, (ii) Multiple Regression Analysis and (iii) Z- test Statistics.

\section{Productivity Index}

This tool was employed to ascertain cassava productivity in the flood affected and control communities. The model is specified thus:

Productivity $(\mathrm{Kg} / \mathrm{Ha})=\mathrm{P}_{1}(\mathrm{Kg}) / \mathrm{A}_{1}(\mathrm{Ha}) \ldots(1)$

Where:

$\mathrm{P}_{1}=$ Output of $\mathrm{i}_{\text {th }}$ Farmer in Kilogram

$\mathrm{A}_{1}=$ Area of Farm-land Cultivated in Hectares

\section{Multiple Regression Analysis}

The Multiple Regression Analysis model was used to ascertain the effect of flood on the productivity of the farmers. The combined regression analysis is specified as follows:

$\mathrm{Y}=\mathrm{a}_{0}+\mathrm{b}_{1} \mathrm{X}_{1}+\mathrm{b}_{2} \mathrm{X}_{2}+\mathrm{b}_{3} \mathrm{X}_{3}+\mathrm{b}_{4} \mathrm{X}_{4}+\mathrm{b}_{5} \mathrm{X}_{5}+$ $\mathrm{b}_{6} \mathrm{X}_{6}+\mathrm{b}_{7} \mathrm{X}_{7}+\mathrm{b}_{8} \mathrm{X}_{8}+\mathrm{e}$

$\mathrm{Y}=$ Productivity of Cassava

$\mathrm{a}_{0}=$ Constant term

$b_{\mathrm{s}}=$ Coefficients of the independent variables

$\mathrm{X}_{1}=$ Flood $(1=$ Affected by Flood; $0=$ Not Affected by Flood)

$\mathrm{X}_{2}=$ Tree Crop Grown $(1=$ Yes; $0=$ No $)$

$\mathrm{X}_{3}=$ Hired Labour (Man-days)

$\mathrm{X}_{4}=$ Total Cost of Weeding $(\mathrm{N})$

$\mathrm{X}_{5}=$ Land $(\mathrm{Ha})$

$\mathrm{X}_{6}=$ Improved Cassava Cuttings (Bundles)

$\mathrm{X}_{7}=$ Age of Cassava Farmers (Years)

$\mathrm{X}_{8}=$ Years Spent in School (Yrs)

$\mathrm{e}=$ Error Term

\section{Z - Test of Significance}

The $\mathrm{Z}$ - test was used to compare the significant difference in cassava productivities between the flood affected farmers and the un-affected farmers. The model is specified as follows:

$\mathbf{Z}=\mathbf{X}_{1}-\mathbf{X}_{2} / \sqrt{ } \mathbf{r}_{1+}^{2} \mathbf{r}_{2}{ }_{2} / \mathbf{n}_{1}+\mathbf{n}_{2}$.

Where:

$\mathrm{Z}=$ Test of two means

$\mathrm{X}_{1}=$ Mean Productivity of Farmers Affected by flood
$\mathrm{X}_{2}=$ Mean Productivity of Farmers under Control

$\mathrm{n}_{1}=$ Population of Farmers Affected by flood

$\mathrm{n}_{2}=$ Population of Farmers under Control

$\mathrm{r}^{2}{ }_{1}=$ Variance of Farmers Affected by Flood

$\mathrm{r}_{2}^{2}=$ Variance of Farmers under Control

\section{Results and Discussion}

Socio-economic Characteristics of Farmers

Some of the socio economic characteristics of the farmers included age, sex, marital status, household size, educational level, farming system, labour type, farming experience, exposure to flood and food security status

The mean ages for both the flood affected communities and control were 50 years and 52 years respectively (Table 1 ), implying that most of the farmers were quite old and mature and were probably at the peak of their productive years with many years of experience to take productive decisions to enhance their cassava productivity. The results further revealed that cassava production in the study area was dominated by the male gender given that $97.2 \%$ of the respondents interviewed within the flooded communities were males compared to $2.8 \%$ females. Ironically, all the respondents covered in the control were males (Table 2). This results runs contrary to the result by Adewale et al. (2003) which observed gender was no barrier to active involvement in cassava production. The mean household sizes were 8 persons and 10 persons respectively for the flooded communities and control respectively (Table 3). The implication of this is that majority of the respondents had relatively large household size. This has further implications for decision making and availability of labour farm activities on the assumption that household members will be willing to engage in farm work. Table 4 reveals that majority $(94.4 \%)$ of the flood affected farmers 
acquired one form of education or the other, similar to the scenario in the control where 93\% were educated. The implication is that respondents are in a position to acquire and adopt new innovations. This has become a key factor given the need to embrace climatic prevention and mitigation measures to combat adverse effect of the flood. Table 5 shows that about $48 \%$ and $44 \%$ of the farmers affected by flood embraced mono and mixed cropping respectively compared to $45 \%$ and $47 \%$ observed for farmers in the control. The implication is that a substantial number of the respondents diversified their activities away from only cassava and as such are in a position to cope with unforeseen circumstances which may limit the production of any particular crop, such as the incidence of flood on cassava in the study area. The result is also a pointer that the respondents may have been involved in sustainable management practices such as crop rotation or cultivation of complementary crops incorporating legumes. Table 6 shows that $60.6 \%$ of the flood affected respondents had previous experience of flood compared to $8.2 \%$ recorded under the control. The result has implication for the ability of the affected farmers to effectively cope with new flood incidences or disasters and the type of coping strategies they would be willing to adapt.

Table 1: Distribution of Respondents According to Age

\begin{tabular}{lllllll}
\hline \multicolumn{3}{l}{ Flood affected Farmers } & & \multicolumn{3}{l}{ Control } \\
\hline Age (years) & Frequency & $\%$ & Mean & Frequency & $\%$ & Mean \\
$31-40$ & 6 & 8.5 & & 2 & 4.1 & \\
$41-50$ & 37 & 52.1 & 50 & 19 & 38.8 & 52 \\
$51-60$ & 23 & 32.4 & & 26 & 53.1 & \\
$>60$ & 5 & 7.0 & & 2 & 4.1 & \\
Total & 71 & 100 & & 49 & 100 & \\
\hline
\end{tabular}

Table 2: Distribution of Respondents According to Sex

\begin{tabular}{|c|c|c|c|c|}
\hline & \multicolumn{2}{|c|}{ Flood affected Farmers } & \multicolumn{2}{|l|}{ Control } \\
\hline Sex & Frequency & $\%$ & Frequency & $\%$ \\
\hline Male & 69 & 97.2 & 49 & 100 \\
\hline Female & 2 & 2.8 & 0 & 0 \\
\hline Total & 71 & 100 & 49 & 100 \\
\hline
\end{tabular}

Table3: Distribution of Respondents by Household Size

\begin{tabular}{lllllll}
\hline \multicolumn{3}{l}{ Flood affected Farmers } & \multicolumn{3}{l}{ Control } \\
\hline $\begin{array}{l}\text { Household } \\
\text { Size }\end{array}$ & Frequency & $\%$ & Mean & Frequency & $\%$ & Mean \\
\hline $1-5$ & 14 & 19.7 & & 9 & 18.4 & \\
$6-10$ & 42 & 59.2 & 8 & 21 & 42.9 & 10 \\
$11-15$ & 13 & 18.3 & & 13 & 26.5 & \\
$16-20$ & 2 & 2.8 & & 4 & 8.2 & \\
$>20$ & - & - & 2 & 4.1 & \\
Total & 71 & 100 & & 49 & 100 & \\
\hline
\end{tabular}


Table 4: Distribution of Respondents According to Educational Status

\begin{tabular}{lllll}
\hline & \multicolumn{2}{l}{ Flood affected } & Farmers & Control \\
\hline Educational Status & Frequency & $\%$ & Frequency & $\%$ \\
None & 4 & 5.6 & 4 & 8.2 \\
Tertiary & 12 & 16.9 & 14 & 28.6 \\
Secondary & 42 & 59.2 & 15 & 30.6 \\
Primary & 7 & 9.9 & 14 & 28.6 \\
Adult Education & 2 & 2.8 & 1 & 2.0 \\
Islamic & 4 & 5.6 & 1 & 2.0 \\
Total & 71 & 100 & 49 & 100 \\
\hline
\end{tabular}

Table 5: Farming Systems Practiced by Respondents

\begin{tabular}{|c|c|c|c|c|}
\hline & \multicolumn{2}{|c|}{ Flood affected Farmers } & \multicolumn{2}{|l|}{ Control } \\
\hline Farming Systems & Frequency & $\%$ & Frequency & $\%$ \\
\hline Monocropping & 31 & 43.7 & 23 & 46.9 \\
\hline Mixed cropping & 34 & 47.9 & 22 & 44.9 \\
\hline Shifting cultivation & 6 & 8.5 & 4 & 8.2 \\
\hline Total & 71 & 100 & 49 & 100 \\
\hline
\end{tabular}

Table 6: Respondents' Past Experience of Flood Occurrence

\begin{tabular}{|c|c|c|c|c|}
\hline & \multicolumn{2}{|c|}{ Flood affected Farmers } & \multicolumn{2}{|l|}{ Control } \\
\hline $\begin{array}{l}\text { Experience } \\
\text { Status }\end{array}$ & Frequency & $\%$ & Frequency & $\%$ \\
\hline Yes & 34 & 60.6 & 4 & 8.2 \\
\hline No & 28 & 39.4 & 45 & 91.8 \\
\hline Total & 71 & 100 & 49 & 100 \\
\hline
\end{tabular}

Estimation and Comparison of Cassava Productivity between Farmers in Flood Affected Communities and the Control

To ascertain the effect of flood on cassava productivity in the flood affected communities, efforts was first made to ascertain the cassava productivities from the flood affected communities and control using the productivity index, after which the cassava productivities from the two population were compared using the Z-test of two means. The results of the productivity analysis and the Z-test are detailed in Table 7 below. 
Table 7: Results of Cassava Productivity Index and Z- test of Two Means

\begin{tabular}{lllll}
\hline Variables & Flood affected Farmers & & Control & \\
\hline & & $\mathrm{N}$ & & $\mathrm{N}$ \\
Production & $588,347.9$ & & 886,000 & \\
Area (Ha) & 89 & 71 & 56 & 49 \\
Productivity (Kg/Ha) & $6,610.65$ & & $14,930.00$ & \\
Z-calculated & 2.54 & & & \\
\hline
\end{tabular}

The result from Table 7 shows that that cassava productivity of the flood affected farmers was $6,610.65 \mathrm{~kg} / \mathrm{ha}$ compared to the $14,930 \mathrm{~kg} / \mathrm{ha}$ under control. This represents a decrease of about $55.72 \%$ relative to the yield under the control and a measure of the loss incurred by farmers due to flood disaster. The Z-test of significance between the two populations further indicated there was a significant difference between the two populations given that the $\mathrm{Z}$ calculated value of 2.54. The result of the "with and without" analysis is an indication that the disparity in yield between the two populations must have been as a result of the flood.

\section{Effect of Flood on Cassava Productivity} among Respondents

The effect of the flood incidence on cassava productivity was further determined using a multiple regression analysis. The results from the analysis are as presented below:

Table 8: Effect of Flood on Cassava Productivity among Respondents

\begin{tabular}{lll}
\hline Variables & Coefficient & T-statistics \\
\hline Constant & 6.284754 & $3.69^{* * *}$ \\
Flood $\left(\mathrm{X}_{1}\right)$ & -1.1661191 & $-7.74^{* * *}$ \\
Practiced Agro-forestry $\left(\mathrm{X}_{2}\right)$ & -0.2936693 & $-1.73^{*}$ \\
Hired labour $\left(\mathrm{X}_{3}\right)$ & 0.1800689 & $1.81^{*}$ \\
Total weeding cost $\left(\mathrm{X}_{4}\right)$ & 0.45753 & 1.40 \\
Land $\left(\mathrm{X}_{5}\right)$ & -0.03438 & 0.88 \\
Cost of cassava cuttings $\left(\mathrm{X}_{6}\right)$ & 0.07656 & 1.32 \\
Age of cassava farmers $\left(\mathrm{X}_{7}\right)$ & 0.6651399 & $1.73^{*}$ \\
Years in school $\left(\mathrm{X}_{8}\right)$ & 0.0028339 & 0.02 \\
$\mathrm{R}^{2}$ & & 0.4586 \\
Adjusted $\mathrm{R}^{2}$ & & 0.4196 \\
$\mathrm{~F}-$ Ratio & & $0.0000^{* * *}$ \\
\hline$* * *=1 \%$ Level of Significance & & \\
$*=10 \%$ Level of Significance & &
\end{tabular}

From the above regression result, the $\mathrm{R}^{2}$ value of 0.4586 shows that $45.86 \%$ of the variation in cassava productivity was accounted for by eight included variables put together. The adjusted $\mathrm{R}^{2}$ also supported the claim with a value of 0.4196 or $41.96 \%$. This implies that the independent variables explained the behavior of the dependent variable. The calculated F-statistics probability value of 0.0000 implies that there is a significant impact between the dependent variables and the independent variables. From the result, flood $\left(\mathrm{X}_{1}\right)$ has a negative significant effect on the productivity of cassava in the study area at $1 \%$ level of significance. This implies that flood has an inverse effect on cassava productivity meaning that every unit increase in flood will result in $-1.17 \%$ decrease in cassava productivity. The result further indicates that 
the adoption of agro-forestry practice of alley cropping had a negative effect on cassava productivity. This result runs contrary to a priori expectations but well explained by the spaces created in the alley farming layout. However, hired labour $\left(\mathrm{X}_{3}\right)$ and Age $\left(\mathrm{X}_{7}\right)$ were significant at $10 \%$ significant levels, implying the as more hired labour are employed and farmer ages, cassava productivity is likely to increase in the study area.

\section{Coping Strategies Adopted by Flood affected Cassava Farmers following the Disaster}

Table 9 shows the coping strategies adopted by flood affected respondents after the flood disaster. From the result, $85.92 \%$ of the respondents adopted new farming systems involving mixed cropping while $42.25 \%$ relied on safety nets mounted by foreign organizations and non- governmental organizations. The ensuing result implies that the adoption of these coping strategies will obviously limit the impact of the flood disaster. However, much depends on the affected farmers to urgently review their lifestyles and production practices, with a view to effectively cope with future incidences of natural disasters such as flood. It also calls for higher performance by early warning signal agencies of the government and development partners to keep farmers alert for timely weather information before engaging in planting of cassava or other crops.

Table 9: Coping Strategies Adopted by Flood Affected Farmers After the Disaster

\begin{tabular}{lll}
\hline Coping Strategies Adopted & Frequency* & $\%$ \\
\hline Adoption of New farming System & 61 & 85.92 \\
Government donations & 36 & 50.07 \\
Support from friends and relatives & 43 & 60.56 \\
Foreign organizations and NGOs & 30 & 42.25 \\
Personal savings & 40 & 56.34 \\
\hline
\end{tabular}

* Multiple Responses

\section{Conclusion and Recommendations}

Arising from the study, it is obvious that the flood had an adverse effect on cassava productivity among the respondents. It thus therefore becomes imperative that (i) more cassava farmers in the study area change their farming practices and behaviours through adoption of sustainable management practices such as diversification of production to mitigate the effect of future occurrence of flood; (ii) the National Emergency Management Agency (NEMA) should in conjunction with the Nigerian Meteorological Agency (NIMET), Kogi State Government and the Media create effective climatic situation awareness for cassava farmers within the state with the view to containing and minimizing the adverse effect of future natural hazards, including flooding; (iii) Kogi State Government provide incentives to create cassava farmers access to climate index insurance in order to adapt to climate change in line with the vision of the on-going Agricultural Transformation Agenda (iv) the private agro-input dealers incorporate climatic information dissemination as part of their designated mandates; (v) experienced farmers should be encouraged to embark on cassava production without prejudice to commercialization.

\section{References}

Action Aid (2006). Climate Change, Urban Flooding and the Rights of the Urban Poor in African Cities. FCT, Abuja, Nigeria.

Bariweni, P., Tawari, C., and Abowei, J. (2012). Some Environmental Effects of 
Flooding in the Niger- Delta region of Nigeria. International Journal of Fisheries and Aquatic Sciences. 1(1): 35-46.

Building Nigeria's Response to Climate Change (BNRCC), (2012). Learning from Experience-Community-Based Adaptation to Climate Change in Nigeria. Produced with the Support of the Government of Canada and Canadian International Developing Agency (CIDA) Pp. 16.

Enete, A.A. (2003). Resource Use, Marketing and Diversification Decisions in Cassava Producing Households in SubSaharan Africa. A Ph.D Dissertation Department of Agricultural Economics, Catholic University of Louvain, Belgium.

Food and Agriculture Organization (FAO), (2009). Climate Change in Africa. The threat to Agriculture. http//www.fao.org.africa.

Gadain, H.M., Bidault, N., Stephen, L., Watkins, B., Dilley, M. and Mutunga, N. (2006).Natural Disaster Hotspots: Case Studies, Reducing the Impacts of Floods through Early warning and Preparedness: A Pilot Study for Kenya', Disaster Risk Management Series No. 6, Washington DC: World Bank).

Gichere, S.K., Olado, G., Anyona, D.N., Matano, A.S., Dida, G.O., Abuom,
P.O., Amayi, J and Ofulla, A.V.O. (2013). Effects of Drought and Floods on Crop and Animal Losses and Socioeconomic Status of Households in the Lake Victoria Basin of Kenya. Journal of Emerging Trends in Economics and Management Sciences (JETEMS) 4(1): 31- 41.

Intergovernmental Parliament for Climate Change (IPCC), (2014) IPCC Report Food Production and Food Security. Cambridge University Press, UK.

National Emergency Management Agency (NEMA), (2012). Report on Flood Disaster in Nigeria. FCT - Abuja, Nigeria

National Population Commission (NPC), (2007). Nigeria Population Figures, National Planning Commission, FCT Abuja, Nigeria.

National Programme for Food Security (NPFS), (2011). Agricultural Production Survey Report (APS), Abuja, Nigeria.

Nwaobiala, C.U. and Nwosu, I.E. (2014). Effect of Climate Change on Cassava Farmers' Output in Cross River State, Nigeria. International Journal of Agric \& Rural Development. Volume 17(1):1628-1634.

Stephen, A. (2011). River Systems and Causes of Flooding Report. Tulane University, EENS 2040. 